\title{
Farmers' Perception of Water Contribution to Household and Farming System in the Offinso North District of Ghana: Rainfall a Critical Climatic Factor
}

\author{
Mercy A. A. Derkyi ${ }^{16}$ \\ University of Energy and Natural Resources, Sunyani \\ Department of Forest Science \\ mercy.derkyi@uenr.edu.gh \\ Nana S. A. Derkyi \\ University of Energy and Natural Resources, Sunyani \\ Renewable Energy Engineering Department \\ and \\ Anthony Baidoo \\ University of Energy and Natural Resources, Sunyani \\ Centre for Climate Change and Gender Studies \\ DOI//http://dx.doi.org/10.4314/gjds.v13i2.6
}

\begin{abstract}
Water resources are increasingly under pressure from population growth, economic activity, and climate change/variability. Using survey and community meetings, the paper analyzed water resources accessible to three farming communities in the Offinso North District and the effects of rainfall changes on their farming livelihood. The study revealed that the households depended on water from three sources, namely: groundwater through boreholes for drinking and domestic use; surface water through streams for drinking, domestic use and irrigating vegetable farms and atmospheric water (i.e. rainfall) for farming. For about $80 \%$ of the respondents, changes in rainfall pattern adversely affected their crops yield which has implication on their livelihoods. Access to irrigation facilities was virtually absent. Also, the non-application of water harvesting techniques for farming thus left these smallholder farmers to the 'mercies of the weather'. Education on climate change and adaptation strategies coupled with technological know-how on water management is recommended for the communities in this forest-savanna transition zone where abrupt changes in rainfall pattern are new to their livelihoods.
\end{abstract}

Keywords: Water Resources, Rainfall, Climate Change, Farming Households, Farm Productivity

16. Corresponding author: Mercy A. A. Derkyi 


\section{Introduction}

Man's survival on earth is dependent on water resources and that makes water indispensable and essential for community development. Water, in its different forms, uses and management are said to be important and key in current development priorities driving Ghana's goal of achieving sustainable development (National Water Policy (NWP), 2007). As a signatory to international laws, protocols, agreements and declarations, Ghana has the obligations in the management of water resources particularly with other riparian states and the environment (NWP, 2007).

However, water resources are increasingly under pressure from population growth, economic activity, climate change/variability and competition among users (GreenFact, 2006). It is noted that higher temperatures and changes in extreme weather conditions have effects on the availability and distribution of rainfall, snowmelt, river flows and groundwater which further worsen water quality (UN-Water, 2010). Climate change is widely viewed as one of the most significant challenges facing society today. Projections indicate that climate change will result in a large increase in climate shocks, such as floods and drought, and lead to a decline in overall rainfall especially in the already drought-prone environment (Rockström, 2003). Furthermore, climate change is said to have an impact on the global hydrological cycle which brings variation in the patterns of demand and supply of fresh water -a dominant sustainer of agriculture (Turral et al., 2011). The Intergovernmental Panel on Climate Change (IPCC) believes that climate change has already contributed to increasing in annual precipitation, cloud cover and extreme temperatures over the last 50 years (IPCC, 2007).

Agriculture is by far the world's largest land use and $80 \%$ of the land uses are rain-fed with the remaining $20 \%$ under irrigation (Rockström et al., 2003). In Sub-Saharan Africa, 95\% of the cultivated land is under rain-fed agriculture, of which the bulk is smallholder farming (Rockström, 2003; Rockström et al., 2007). Even though rain-fed agriculture contributes globally with an estimated $60 \%$ of world food due to lower yield levels in rain-fed crop production, this farming system will continue in the foreseeable future to be the dominant source of food especially in sub-Saharan Africa (Parr et al., 1990).

Ghana is no exception, its economy is characterized by agriculture, primarily smallscale which contributes about 23\% of the country's GDP in 2012 with significant growth since 2007 with rain-fed, subsistence -based and basic technology driving the sector (FAO, 2015). In Ghana, it is noted that climate change is projected to have severe environmental, economic, and social impacts especially on rural farmers whose livelihoods are largely driven by rainfall (Fosu-Mensah et al., 2010). Agriculture is, however, vulnerable to climate shifts and a significant source of the greenhouse gases (GHGs) that are driving those changes and estimated to generate up to $15 \%$ of total 
global anthropogenic GHG emissions (IPCC, 2007). It is commonly acknowledged that developing countries are more vulnerable to climate change than developed countries in view of the predominance of agriculture in their economies, limited or lack of capital for adaptation actions, warmer baseline climates and increased exposure to extreme events (Parry et al., 2001).

Water resources, on the other hand, affect agriculture production positively and negatively. The negative impact of water on agriculture is likely to increase in the event of uncontrolled climate change and lack of integrated water management to meet agriculture needs (NWP, 2007; Howden et al., 2007; Morton, 2007). At the microlevel, farmers face pressure in adjusting to agricultural systems thus making them less resilient in the face of increasingly variable weather (Arbuckle et al., 2013). The changing trends in climate change and its impacts call for immediate and comprehensive adaptation strategies especially in the agricultural sector (Howden et al., 2007). There is a need to consider water as not only the sustainer of life but also as the sustainer of agriculture and thus map out water management strategies to sustain and effectively manage agriculture. One key strategy is the integrated water resource management (IWRM). It is defined as a process which promotes the coordinated development and management of water, land and related resources, in order to maximize the resultant economic and social welfare in an equitable manner without compromising the sustainability of vital ecosystems (NWP, 2007). Thus, agriculture water management needs to be an integral component of the overall water management (Bouwer, 2000).

Water resources and how they are managed is central to the survival of a society and its economy in the range of health, food production and security, domestic water supply and sanitation, energy, industry, and the functioning of ecosystems (UN-Water, 2010). This is in line with Ghana's Water Vision for 2025 with the key objective to "promote an efficient and effective management system and environmentally sound development of all water resources in Ghana" (NWP, 2007). Future climate changes may also include more weather extremes, like more periods with excessive rainfall and more periods of low rainfall that causes drought. Climate change adaptation is closely linked to water and its role in sustainable development. Recognizing this reality and responding accordingly presents development opportunities. Essential adaptation measures in dealing with climate change and building upon existing land and water management practices have the potential to create resilience to climate change (UN-Water, 2010). Thus enhance water security which directly contribute to the development and these must be complemented by innovative technological practices (UN-Water, 2010).

Protecting water supplies against these extremes and changes call for more longterm planning to build water reserves during times of water shortage (Bouwer, 200o). A combination of irrigation and rain harvest systems are key sources of water storage 
during longest dry periods. Rainwater harvesting has a great potential to increase water availability.

Generally, in Ghana it is recorded that rainfall decreases from the south-west of the country (2000 $\mathrm{mm} /$ year) towards the north (950 $\mathrm{mm} /$ year) and the southeast (8oomm/year) thus with the suitable technologies and incentives, rainfall harvesting could reasonably contribute to household and institutional water needs (NWP, 2007). It is therefore in line that the country has developed a National Rainwater Harvesting Strategy (NRWHS) of 2011 to fulfill the Water Policy objectives. The NRWHS objective is to supplement water service delivery in both urban and rural area. Water management techniques must be such that it will be feasible for smallholder farmers in rural communities and also all year round.

Domestic Rainwater Harvesting (DRWH) system has been an anchor to the populace of the developed and developing regions of South Africa where rainwater harvesting has the potential to supply water to rural and peri-urban areas than conventional water sources and supports small-scale productive activities (Kahinda et. al., 2007). In line with Ghana's water policy, the best approach to harnessing water resources, management, and sustainable use is through an integrated water resources management approach which ensures that water does not become a constraint to national development (NWP, 2007). Effective implementation of this approach is the right path whilst ensuring an allyear-round water supply for agriculture purposes. The objective of this paper, therefore, is to explore smallholder farmers' perception of their dependence on water resources from the atmosphere, ground and surface levels and the effects of rainfall changes on crop production.

\section{Methodology}

A survey was conducted in three communities (Meta, Mentukwa, and Amponsakrom No.2) located in the Offinso North District of the Ashanti Region of Ghana in 2015 (see Fig 1). The overall study sought to find out farmers' perception on natural resources access and control, climatic and socio-economic factors influencing their livelihoods and coping strategies accessible to them. However, this paper presents farmers' perception of their access to water resources and the effect of rainfall changes on their crop production in the forest-savanna transition zone of Ghana. 

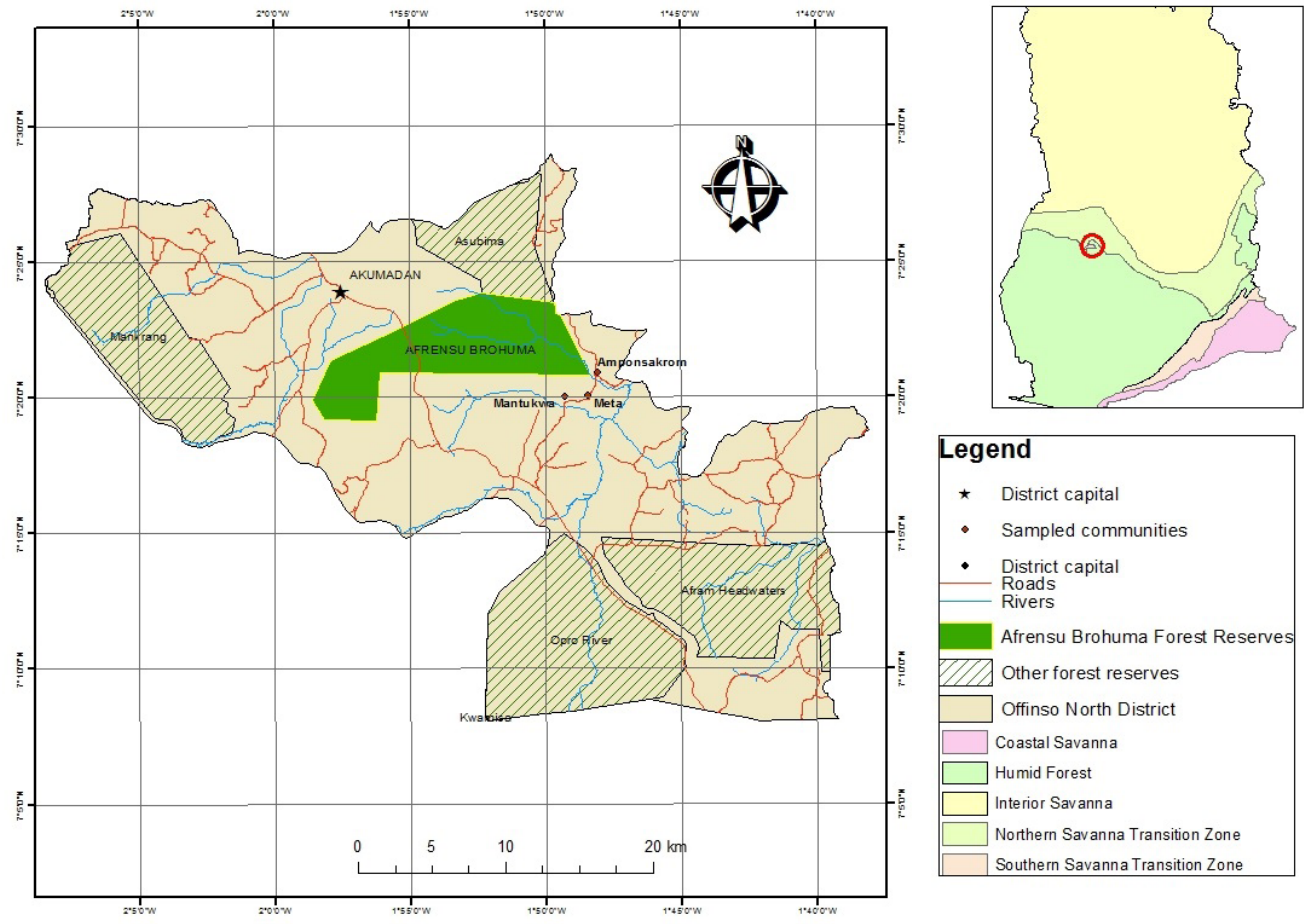

Fig 1: Map of Offinso North districts showing the location of the sampled communities

The predominant occupation in the study communities is farming. Farmers are mostly engaged in food crop farming for commercial purposes. The participants from Amponsakrom No.2 and Meta were predominantly migrants from the Northern, Volta, Upper East and Upper West regions of Ghana, and those from Mantukwa were predominantly natives. Data collection was through a structured questionnaire survey among 59 sampled households in Meta $(\mathrm{n}=16)$, Amponsakrom No.2 ( $\mathrm{n}=8)$ and Mantukwa $(n=35)$ respectively, based on sampled household rate of $20 \%$ as shown in Table 1.

Table 1: Study communities, number of households and sampled number of respondents for survey

\begin{tabular}{|l|l|l|}
\hline Community & No. of households & Sampled number for survey (20\%) \\
\hline Meta & 70 & 16 \\
\hline Mantukwa & 179 & 35 \\
\hline Amponsakrom No.2 & 40 & 8 \\
\hline Total & & 59 \\
\hline
\end{tabular}


The household population size data for the survey in Meta and Mantukwa were accessed from the Planning Officer of the Offinso North District Assembly and confirmed by newly gathered population and the household data from Students from the University of Development Studies that were having their community trimester programme in Mantuakwa community. For that of Amponsakrom No. 2, the elders of the town provided the household data during the reconnaissance visit and this was confirmed during the community meeting. Documents and data from community meetings were content analyzed. Survey data was analyzed using SPSS 21 to generate frequency tables and graphs.

\section{Results and Discussion}

\section{Demographic Characteristics of the Households}

Among the 59 respondents, $53 \%(n=31)$ were household heads, representing $74 \%$ males and $26 \%$ females. While $47 \%$ of the respondents $(n=25)$ were not household heads but mostly the wives of the household heads engaged in the study. In terms of gender, $43 \%$ were males with $57 \%$ being females. For the age ranges, $18-35$ were $41 \%$, 36-54 were $52 \%$ with 55 and above being $7 \%$.

\section{Sources of Water Resources Accessible to Farming Households}

Three different water sources - streams, borehole, and rainfall sources of water for the study communities in the Offinso North District of Ghana. The study communities either depend on the water for their agriculture activities or for domestic purposes for which rainfall (atmospheric water) is key to their agrarian livelihood. Rainfall supply feeds both the water table (underground water) and the Stream (Surface water). These water sources support the findings of Gyau-Boakye (2001) that over 68\% Ghana's population which forms the rural communities rely on surface and groundwater sources for their water supply needs. Ghana's water resources are potentially divided into surface and groundwater sources (NWP, 2007).

\section{Households' Dependency on Surface Water (Streams)}

One of the major sources of water for Amponsakrom No.2, Meta, and Mantukwa communities are streams. From Fig. 2 it is observed that community members depend on natural resources for their sustenance. Key among them is firewood, Non-timber forest products (NTFPs) (e.g. mushroom, snails) and water. When respondents were asked about natural resources essential for their daily activities, water appeared in seven out of nine combinations of resources used according to $92 \%$ of the respondents. 


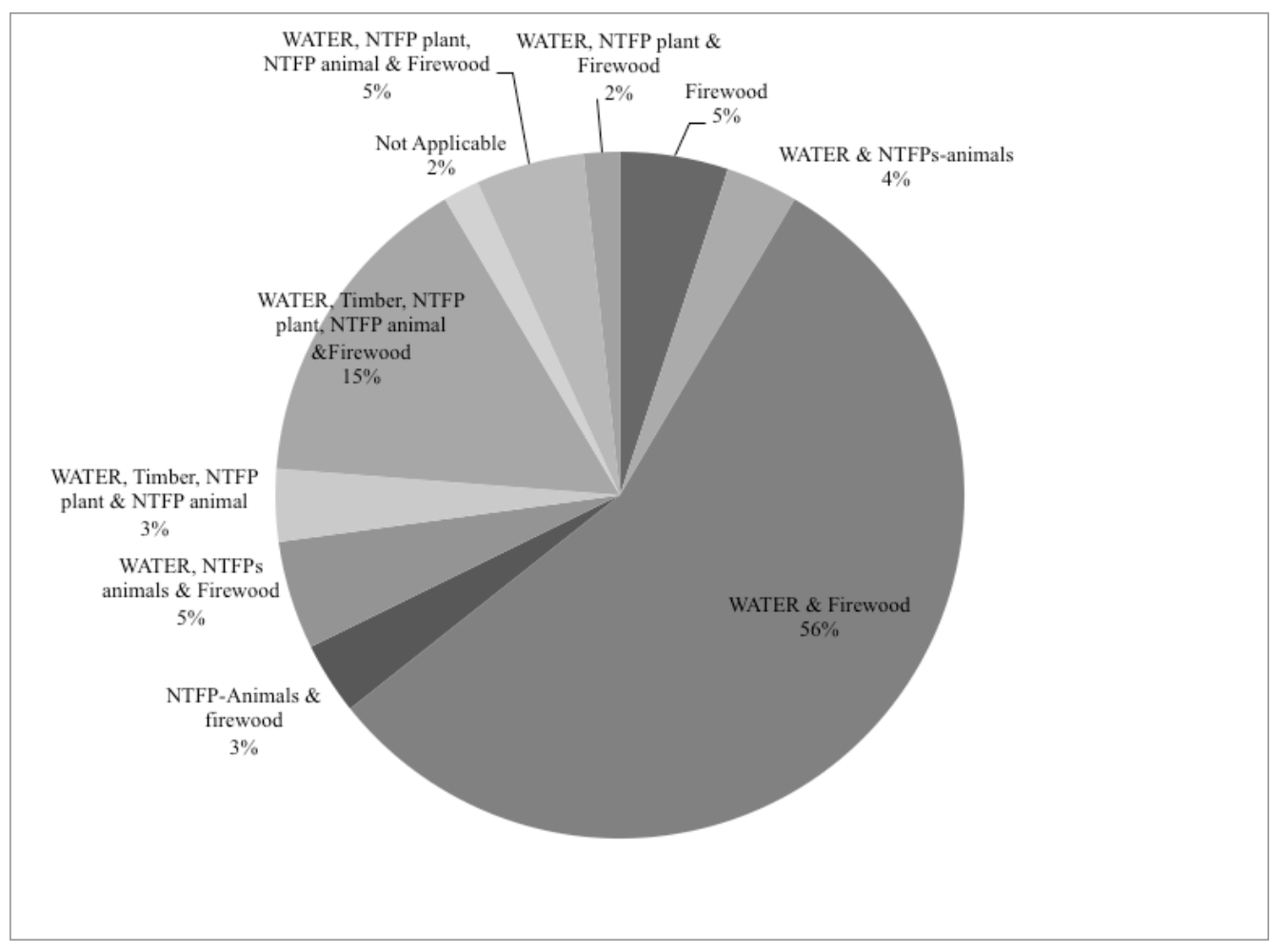

Fig. 2: Percentage distribution of natural resources that farmers depend on daily of which water pivotal $(\mathbf{n}=59)$. Source: Field data, 2015

For these households, water from the streams supports their daily activities and as a result, the scarcity of it threatens their very existence. Owing to the complex and rapidly changing geography of water supply, use and increase pressure on water due to climate change, the future adequacy of freshwater resources is difficult to assess (Vörösmarty et al., 2000). Arnell (2004) asserted that climate change increases water resources stresses in some parts of the world where runoff decreases, including around the Mediterranean, in parts of Europe, central and southern America, and Africa. Water is increasingly becoming a scarce resource even though our need of it always surges forward.

Even though the majority of the study households have access to stream water to facilitate their household chores but according to these household the stream water are not suitable for drinking. For the respondents interviewed at Amponsakrom No. 2 $(n=8)$, the community does not have access to potable water for drinking. Of the three communities, Amponsakrom No. 2 is completely dependent on stream as drinking water since their borehole remains dysfunctional. Community members at Amponsakrom No.2 depend on a stream which is situated close to a very big tree. The study revealed that apart from the stream being at the 'mercies' of erratic rainfall and extreme temperature 
which dries it up intermittently, it is also often polluted by the fallen leaves of the tree and bird feces thus pose a lot of health challenges on the community members. One out of the 16 respondents at Meta stated there was no access to potable water. At Mantukwa, nine out of the 35 respondents stated they had no access to potable water. The situation at Mantukwa is not any different, except that instead of using their stream for only domestic purposes, some community members whose farms are close to the stream use the stream water to irrigate vegetables. This is in line with the findings of Davis et. al. (2003) and Barton (1996) that streams are sources of water for irrigation purposes for smallholder farmers. It is certain from the study that water plays a very important role in the lives of smallholder farmers in these communities. Nonetheless, access to potable water from groundwater (or borehole) remains a challenge which needs to be surmounted. Water is a renewable resource however it is noted that its availability varies and often limited resulting in shortages during a certain period of the year (Pimentel et al., 1997). The issue becomes even more pressing when the smallholder farmers have to consume water which has health implications since they lack access to quality drinking water. The lack of safe water creates a tremendous burden of diarrheal disease and other debilitating life-threatening illnesses for people in the developing world, especially women, and children (NWP, 2007; Sobsey et al., 2008).

\section{Households' Dependency on Boreholes for Drinking and Domestic Use (Groundwater)}

Figure 3 gives a clear indication of community members' access to potable water. Not only do communities need water to undertake their farming activities, they even more so need potable water to facilitate their domestic activities. Bore holes remain very important sources of water for these three communities. They predominantly depend on them for domestic purposes. Meta and Mantukwa have functioning boreholes but Amponsakrom No. 2's bore hole was not functional as at the time of data collection in July 2015. Even within Meta and Mantukwa communities, not all the community members have access to these boreholes due to long distance to the borehole locations and limited boreholes availability compared to population size. Lack of access to the water from the boreholes and its inadequate nature affect agriculture activities since farmers must leave the farms early for the house to compete for the water for domestic use. As asserted by Huisman et. al. (2003) this reduces the yield of farm produce since farmers need to spend the time which needs to be channeled into food production in their respective farms at home struggling for the little water available. 


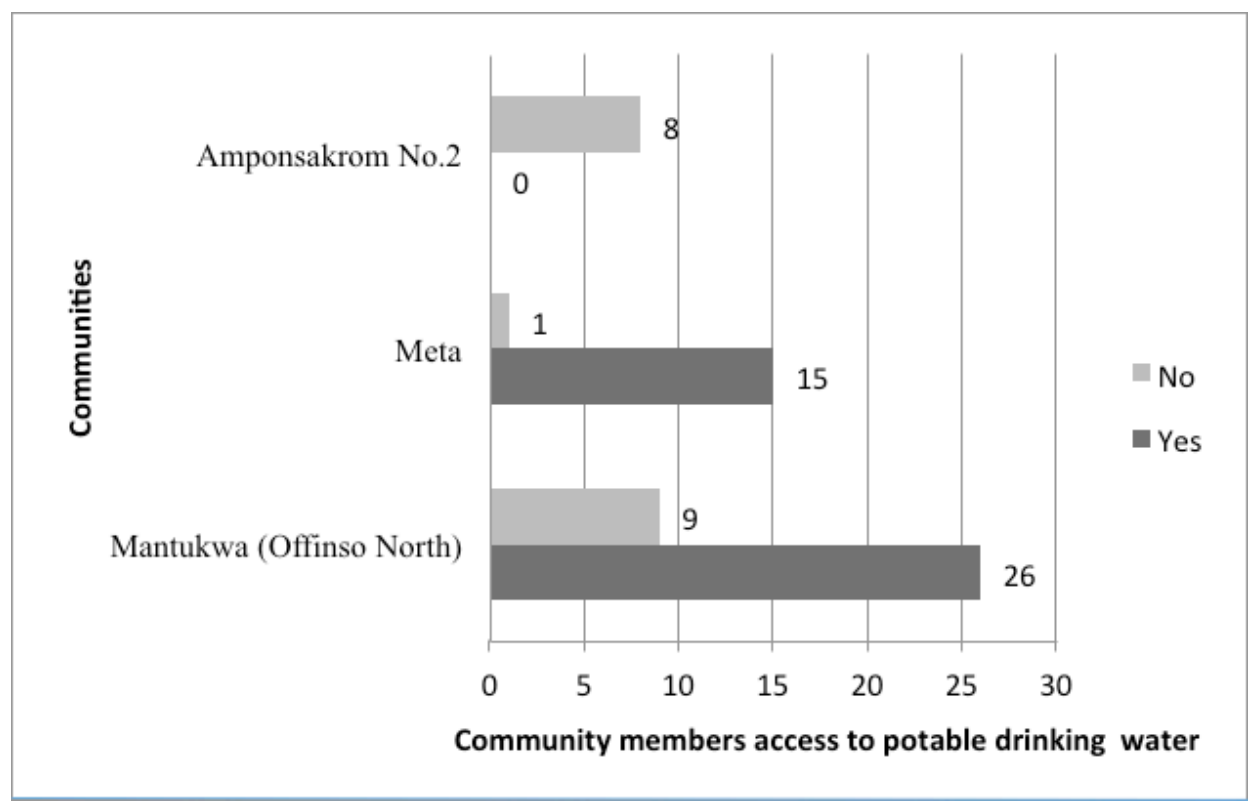

Fig 3: Farming households' access to potable drinking water in the study communities Source: Field data, 2015

\section{Households' Dependency on Rainfall (Atmospheric Water) and Effects on Farming System}

In typical farming practices in sub-Saharan Africa, rural livelihoods are dependent on rain-fed agriculture (see Cooper et al., 2008; Codjoe et al., 2010; Fosu-Mensah et al., 2010; Sissiko et al., 2011).

Rainfall is the single most important source of water in sustaining this agrarian livelihood of which all the study respondents attested to. Smallholder farmers in the study stated that for the past two decades they have observed a decline in rainfall pattern and increase in temperature. They mentioned that the resultant effect on the agriculture activities has been a drastic reduction in crop yield with an unprecedented low yield of crops in 2015. This supports previous studies on the effect of climate change on rain-fed agriculture (Arnell, 1999; Howden et al., 2007; Piao et al., 2010). Rainfall changes observed in these communities were on the basis of timing, duration, intensity, duration, and frequency. For the majority of the respondents $(n=34)$ constituting $61 \%$, these changes in rainfall pattern are in the combination of irregular timing, short duration, high intensity and less frequent rainfall as shown in Table 2. 
Table 2: Respondents views of rainfall changing modes in the past 10-20 years in the study area

\begin{tabular}{|l|l|}
\hline Rainfall changing modes in the past 10-20 years & Number and Percentage of Respondents $(\mathbf{n}=\mathbf{5 6})$ \\
\hline Timing, Duration, and Intensity & $10(18 \%)$ \\
\hline Timing, Duration, and Frequency & $12(21 \%)$ \\
\hline Timing, Duration, Intensity, and Frequency & $34(61 \%)$ \\
\hline Total & $56(100 \%)$ \\
\hline
\end{tabular}

Field data, $2015 *$ Three respondents did not respond to the issue.

Communities meetings held revealed that 2015 was the worse period experienced in terms of irregular rainfall timing, short duration, low intensity and less frequency which resulted in withering and dying of crops especially maize which is among the lead crops cultivated in the area. These observations are in consonant with other reports that indicate that with changing rainfall patterns and an increasing risk of water-related disasters, not only will crop production and food security be affected but there will also be less availability of clean water to meet people's basic needs (Skinner, 2011).

Rainfall is critical in determining agricultural output, the rationale being that most farming system and many aspects of crop growth are adversely affected by rainfall variability, which can have a disproportionate impact because individual crops are affected differently (Kangah, 2004). Figures 4 and 5 provide the importance and absence of rainfall to crop productivity as stated by the smallholder farmers. For the majority of the respondents, regular rainfall brings positive effects on their farming system where there are an increase in crop yield $(n=37)$ resulting in high productivity and food availability whereas it enhances crops growth $(\mathrm{n}=21)$ followed by improved income level $(n=12)$ as reflected in Fig. 4. According to the majority of the respondents, absence or erratic rainfall results in a decrease in crop yield $(\mathrm{n}=37)$, crops withering and dying $(\mathrm{n}$ $=10)$ and less income and poverty $(n=12)$ as shown in Figure 5 . As asserted by Cooper et al. (2008), the ability of agricultural communities and agricultural stakeholders in Sub-Saharan Africa to cope better with the constraints and opportunities of current climate variability must first be enhanced to adapt to climate change and the predicted future increase in climate variability. Supporting this discourse, Kurukulasuriya and Rosenthal (2003) stated that the general consensus is that changes in temperature and precipitation will result in changes in land and water regimes that will subsequently affect agricultural productivity. It is reported that in tropical regions, with many of the poorest countries, impacts on agricultural productivity are expected to be particularly harmful (Howden et al., 2007; Turral et al., 2011). 


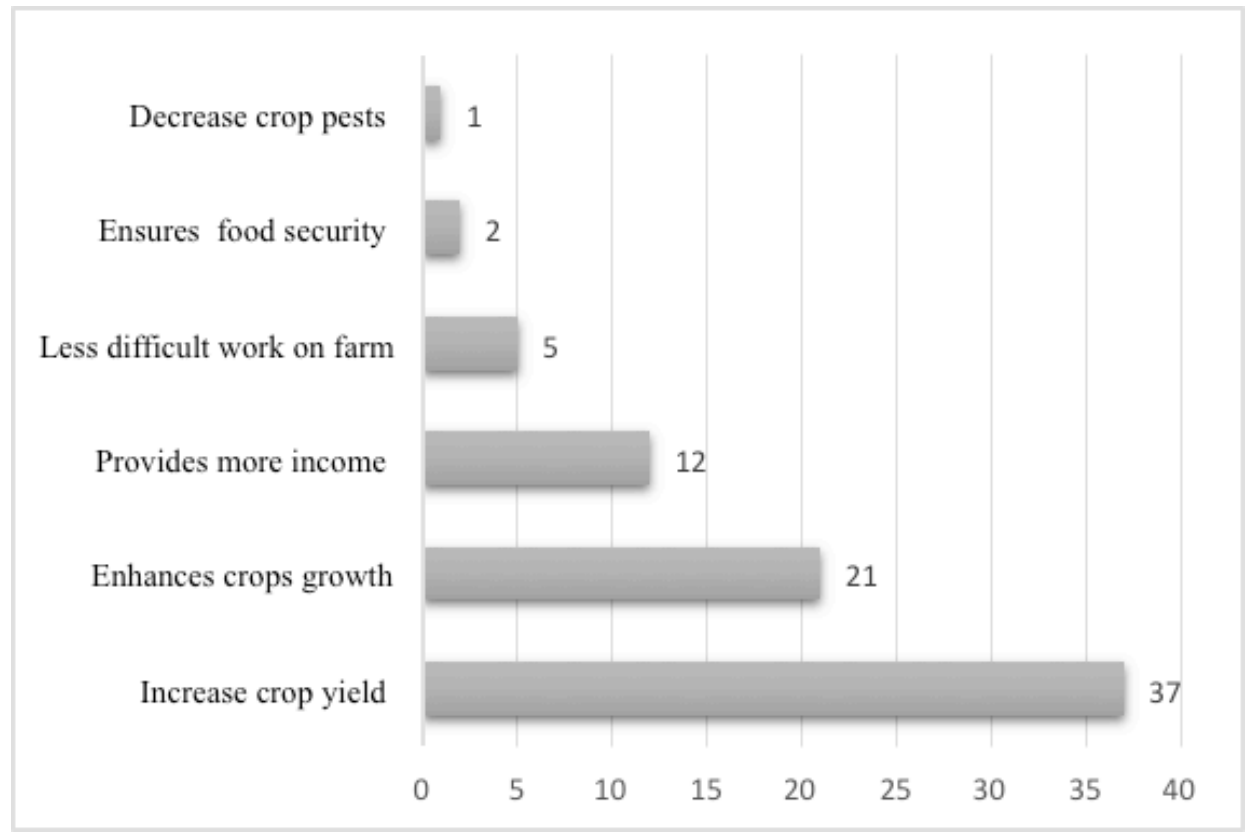

Fig 4: Regular rainfall effects on farmers farm productivity $(n=59)$

Source: Field data, 2015

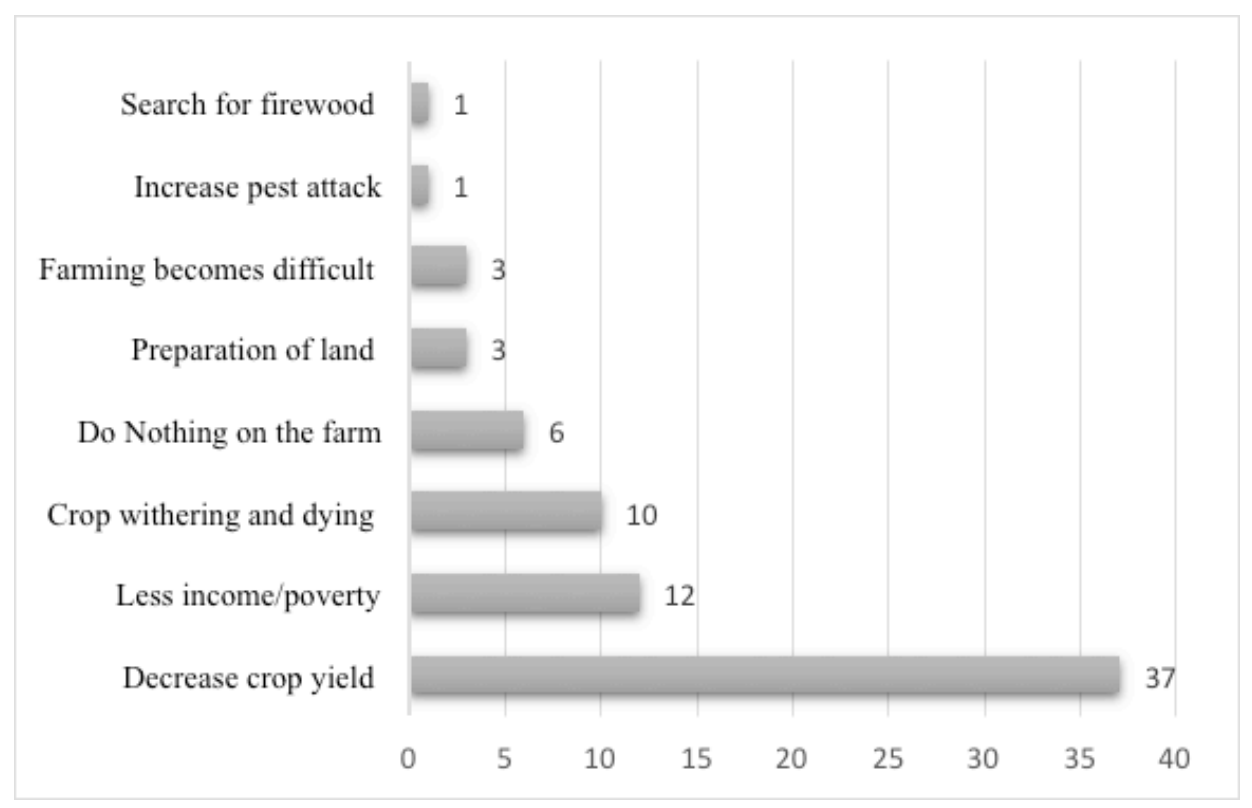

Fig 5: Lack/erratic rainfall effects on farmers farm productivity $(n=59)$

Source: Field data, 2015 
The livelihoods of rural communities are at risk from water-related impacts due to climate change (Turral et al., 2011). It is noted that rain-fed agriculture will remain the dominant source of staple food production and the livelihood foundation of the majority of the rural poor in sub-Saharan Africa (Cooper et al., 2008). Unfortunately, farmers in the study communities are not making full use of rainfall in respect to water harvesting. Thus, Ghana needs to adapt to the changing climatic condition especially with respect to modern technologies to store water to sustain its agrarian society.

\section{Water Adaptation Strategies against Climatic Changes}

Besides the boreholes for drinking water, the study communities do not have access to water security techniques such as irrigation and rainwater harvesting or water storage systems that enhance agriculture productivity. It was ascertained that only a few farmers make use of streams close to their farms for manual irrigation on vegetable farms. Majority continuously wait at the 'mercy' of the weather or favorable rainfall especially in the era of climatic change characterized by erratic/irregular rainfall. The absence of deliberate and constructive decision by the smallholder farmers in the study communities regarding adaptation strategies to overcome crop failure and ultimate poverty undermine the definition of water security 'the capacity of a population to safeguard sustainable access to adequate quantities of acceptable quality water for sustaining livelihoods, human well-being, and socio-economic development, for ensuring protection against water-borne pollution and water-related disasters, and for preserving ecosystems in a climate of peace and political stability' (UN-Water, 2013). Water adaptation against climate change among these agrarian communities calls for more storage facilities. Some of these storage facilities could be naturallyenhancing groundwater recharge through rainwater harvesting, sustainably managing aquifers and nourishing wetlands whiles others may include small, medium or large reservoirs that may not be detrimental to the environment and to the well-being of the communities (Bouwer, 2000; UN-Water, 2013).

On a positive side, Ghana in 2011 finalized its National Rainwater Harvesting Strategy to augment the traditional water supply system. The challenge is how adequately are the actions in this strategy being implemented especially among farming communities where rainfall or water is key to the survival of their livelihoods. Educating and building the capacity of these smallholder farmers' adaptation measures to overcome climatic changes on water resources and linkage to their agriculture system should be the first step to enhance rural livelihoods. Nevertheless, the efforts of these farmers need to be complemented by the efforts of the water managers as well as the nations where the water management techniques will be feasible for smallholder farmers in rural communities and also all year round. The success stories for sustaining water storage facilities could be learned to help the smallholder farmers in Ghana especially in the 
study communities overcome their high dependencies on relaying at the 'mercies of the weather'. As indicated by Kahinda et. al. (2007), the Domestic Rainwater Harvesting (DRWH) project in South Africa provides water directly to households enables a number of small-scale productive activities, has the potential to supply water even in rural and peri-urban areas than conventional water supply. Similarly, the Water Research Institute and the Science and Technology Policy Research Institute of the Council for Scientific and Industrial Research in fulfilling some aspect of the National Rainwater Harvesting Strategy initiated the 'Rainwater harvesting (RWH) resilience to climate change impact on water availability in Ghana' project in collaboration with Norway Research Centre and with funding from Nordic Development Fund. Among the objectives, the project focus was more on Urban RWH in contrast to the call from this paper for enhancing the rural RWH and other facilities in order to boost agriculture. This initiative together with the clearly stated action plans of the NRWHS need to be replicated nationwide. More especially among the farmers in the transition zone who have been experiencing frequent erratic rainfall and extreme temperature which hitherto were not so and regrettably adaptation to sustain their farming livelihoods are non-existing or limited. Stakhiv and Stewart (2009) presented five adaptation measures of which water managers need to adapt to this contemporary climate change. One of the key measure of relevance to this paper in minimizing the climatic stress of the smallholder farmer especially in forest -savanna transition zone with limited or no adaptation strategies is 'planning and applying new investments (for example, reservoirs, irrigation systems, capacity expansions and ecosystem restoration)'. There is a clear indication that water - related climate change adaption has a pivotal role in achieving sustainable development and this must be guided by these six principles - i) mainstream adaptations within the broader development context; ii) strengthen governance and improve water management; iii) improve and share knowledge and information on climate and adaptation measures and invest in data collection; iv) invest in cost-effective and adaptive water management as well as technology transfer; and v) leverage additional funds through both increased national budgetary allocations and innovative funding mechanisms for adaptation in water management (UN-Water, 2010: 2).

\section{Conclusions}

The activities of man and climate change constantly pose pressure to water resources which are the primary medium through which climate change influences Earth's ecosystem and thus the livelihood and well-being of societies. From our study and earlier findings, it is undoubtedly clear that there is a need for an all-inclusive water management strategy to ensure that there is an all-year-round water supply for both agriculture and domestic purposes. Smallholder farmers are increasingly feeling the effects of climate changes, especially on their crop production. Although most farmers 
desire a suitable way to adapt to climate change, they are not well resourced and informed to do so. With the country's water policy and NRWHS in place, the next step is nationwide upscaling of the aforementioned water storage facilities especially in the agrarian communities where rainfall or water is the key determinant of their well-being. It is therefore recommended that district level institutions such as Department of Food and Agriculture, District Assemblies, Ghana Water Cooperation, Non-governmental institutions should educate local people on climate change and adaptation strategies. This must be coupled with technological know-how on water management in this transition zone where abrupt changes in rainfall pattern are new to their livelihoods.

\section{Acknowledgement}

This paper is part of the first author's post-doctoral research. The first author is grateful to the research funds from the Department for International Development (DfID) under the Climate Impact Research Capacity and Leadership Enhancement (CIRCLE) programme"; Management and Staff of the University of Energy and Natural Resources (UENR) - Ghana, Climate change research group and the Regional Institute for Population Studies (RIPS) of the University of Ghana which hosted the first author through the period of the fellowship. We also acknowledge the two anonymous reviewers for their constructive review.

\section{References}

Arbuckle, J. G. J., Morton, L. W., and Hobbs, J. (2013). Understanding farmer perspectives on climate change adaptation and mitigation: The roles of trust in sources of climate information, climate change beliefs, and perceived risk. Environment and Behavior, 42, pp. 205-234.

Arnell, N. W. (1999). Climate change and global water resources. Global Environmental Change, 9, S31-S49.

Arnell, N. W. (2004). Climate change and global water resources: SRES emissions and socio-economic scenarios. Global Environmental Change, 14(1), pp. 31-52.

Barton, D. (1996). The use of Percent Model Affinity to assess the effects of agriculture on benthic invertebrate communities in headwater streams of southern Ontario, Canada. Freshwater Biology, 36 (2), pp. 397-410.

Bouwer, H. (2000). Integrated water management: emerging issues and challenges. Agricultural Water Management, 45(3), pp. 217-228. 
Codjoe, S.N.A., Atidoh, L.K. and Burket, V. (2011). Gender and occupational perspectives on adaptation to climate extremes in the Afram Plains of Ghana. Climate Change, 110:431 Springer.

Cooper, P. J. M., Dimes, J., Rao, K. P. C., Shapiro, B., Shiferaw, B. and Twomlow, S. (2008). Coping better with current climatic variability in the rain-fed farming systems of sub-Saharan Africa: An essential first step in adapting to future climate change? Agriculture, Ecosystems and Environment, 126(1), pp. 24-35.

Davis, S., Golladay, s. W., Vellidis, G., and Pringle, C. M. (2003). Macroinvertebrate bio-monitoring in intermittent coastal plain streams impacted by animal agriculture. Journal of Environmental Quality, 32(3), pp. 1036-1043.

FAO (2015). Country fact sheet on food and agriculture policy trends. Socio-economic context and role of agriculture. Food and Agriculture Policy Decision Analysis, Ghana.p.6.

Fosu-Mensah, B.Y., Vlek, P.L.G., and Manschadi, A.M., (2010). Farmers' Perception and Adaption to climate change: A case study of Sekyedumasi District in Ghana. Tropentag, September 14-16, Zurich. World Food System-A Contribution from Europe.

Green Facts (2006). Facts on water resources. A summary of the United Nations World Water Development Report 2. p. 6. Available at: http://www.greenfacts.org/en/ water-resources/water-resources-foldout.pdf Accessed 24th October, 2016.

Gyau-Boakye, P. (2001). Sources of rural water supply in Ghana. Water International, 26(1), pp. 96-104.

Howden, S. M., Soussana, J. F., Tubiello, F. N., Chhetri, N., Dunlop, M., and Meinke, H. (2007). Adapting agriculture to climate change. Proceedings of the National Academy of Sciences, 104(50), pp.19691-19696.

Huisman, J. A., Hubbard, S. S., Redman, J. D., and Annan, A. P. (2003). Measuring soil water content with ground penetrating radar. Vadose Zone Journal, 2(4), pp. 476-491.

IPCC (2007). Climate Change 2007: Synthesis Report. Contribution of Working Groups I, II and III to the Fourth Assessment Report of the Intergovernmental Panel on Climate Change [Core Writing Team, Pachauri, R.K and Reisinger, A. (eds.)]. IPCC, Geneva, Switzerland, p.104. 
Kahinda, J. M. M., Taigbenu, A. E. and Boroto, J. R. (2007). Domestic rain.water harvesting to improve water supply in rural South Africa. Physics and Chemistry of the Earth, Parts A/B/C, 32(15), pp.1050-1057.

Kurukulasuriya, P. and Rosenthal, S. (2003). Climate change and agriculture: A review of impacts and adaptations, World Bank Climate Change Series (World Bank Environment Department, Washington, DC), 91, p. 96.

Morton, J. F. (2007). The impact of climate change on smallholder and subsistence agriculture. Proceedings of the national academy of sciences, 104(50), pp. 1968019685.

National Water Policy (2007). Ministry of Water Resources, Works and Housing, the Government of Ghana.

Pandey, N. (2005). Societal adaptation to abrupt climate change and monsoon variability: Implications for sustainable livelihoods of rural communities. Report, Winrock International-India, New Delhi.

Parr, J.F., Papendick, R. L., Hornick, S. B., Meyer, R. E. (1990). Strategies for developing low-input sustainable farming systems for rain-fed agriculture. In: Proc. Intl. Symposium for Managing Sandy Soils, February 6-11, 1989, Jodhpur, India. Indian Council of Agricultural Research. New Delhi.

Parry, M.L., Arnell, N.W., McMichael, A.J., Nicholls, R.J., Martens, P., Kovats, R.S., Livermore, M.T.J., Rosenzweig, C., Iglesias, A., and Fischer, G. ( 2001). Millions at risk: Defining critical climate change threats and targets. Global Environmental Change, 11, pp.181-183.

Piao, S., Ciais, P., Huang, Y., Shen, Z., Peng, S., Li, J., Zhou, L., Liu, H., Ma, Y., Ding, Y.,Friedlingstein, P., Liu, C., Tan, K., Yu, Y., Zhang. T., and Fang, J. (2010). The impacts of climate change on water resources and agriculture in China. Nature, 467(7311), pp. 43-51.

Pimentel, D., Houser, J., Preiss, E., White, O., Fang, H., Mesnick, L., Barsky, T., Tariche, S., Schreck, J., and Alpert, S. (1997). Water resources: Agriculture, the environment, and society. An assessment of the status of water resources. BioScience, pp.97-105.

Rockström, J. (2003). Water for food and nature in drought-prone tropics: vapor shift in rain-fed agriculture. Phil. Trans. R.Soc. Land. B. 358 pp.1997-2009.

Rockström, J, Barron, J and Fox, P. (2003). Water productivity in rain-fed agriculture: Challenges and opportunities for smallholder farmers in drought-prone tropical 
agroecosystems. In J.W. Kijne, R. Barker and D. Molden, (eds), Water productivity in agriculture: Limits and opportunities for Improvement, pp.145-162. CAB International

Rockström, J., Wani, S., Oweis, T. and Hatibu, N. (2007). Managing water in rainfed agriculture. In Water for food, water for life: a comprehensive assessment of water management in agriculture. Sponsored by Ramsar, CGIAR, FAO and CBD. EarthScan, London, UK, pp. 315-348.

Sissoko, K., van Keulen, H., Verhagen, J., Tekken, V. and Battaghlini, A. (2011). Agriculture, livelihoods and climate change in the West African Sahel. Reg. Environ Change, 11, s119-s125.

Sobsey, M. D., Stauber, C. E., Casanova, L. M., Brown, J. M., and Elliott, M. A. (2008). Point of use household drinking water filtration: a practical, effective solution for providing sustained access to safe drinking water in the developing world. Environmental Science and Technology, 42(12), pp. 4261-4267.

Stajhiv, E. and B. Stewart (2009). White paper: Needs of climate information for decision-making in the water sector. Paper produced for World Climate Conference - 3, 31 August - 4 September 2009. Available at: http://www.waterandclimate. org/UserFILE/WWW2009 Water sector Needs-White Paper Ver 3_Numbered.doc. Accessed 15th March, 2016.

Skinner, E (2011). Gender and climate change overview report. BRIDGE developmentgender. Institute of Development Studies, p. 85.

Turral, H., Burke, J. J., and Faurès, J. M. (2011). Climate change, water and food security. Rome: Food and Agriculture Organization of the United Nations. Water Report 36. FAO, Italy.

UN-Water (2013). Analytical brief water security and the global water agenda-4-page summary for decision makers.

UN-Water (2010). Climate change adaptation: the pivotal Role of water. Policy and Analytical Briefs.

Vörösmarty, C. J., Green, P., Salisbury, J., and Lammers, R. B. (2000). Global water resources: vulnerability from climate change and population growth. Science, 289(5477), pp. 284-288. 